DOI: 10.15290/aipan.2020.03

\title{
Uniwersalny wymiar niepełnosprawności
}

\author{
Karol Kuźmicz \\ Uniwersytet w Białymstoku \\ k.kuzmicz@uwb.edu.pl \\ ORCID: https://orcid.org/0000-0002-3914-5499
}

\section{Wprowadzenie}

O problemach związanych $\mathrm{z}$ niepełnosprawnością słusznie mówi się z rozmaitych punktów widzenia. Sprzyja temu również tak popularne dzisiaj interdyscyplinarne podejście, pozwalające na bardziej wszechstronne podejście do tego tematu. Obecnie należy go bowiem ujmować w sposób praktyczny, związany z poszukiwaniem odpowiedzi na pytanie, w jaki sposób na co dzień żyć i radzić sobie z niepełnosprawnością oraz jak rozwiązywać problemy, które ona warunkuje, a które mogą ułatwić, usprawnić czy ulepszyć życie ludzi mających przede wszystkim kontakt bezpośredni z niepełnosprawnością własną lub innych ludzi.

Niniejsze rozważania, mające charakter subiektywny i teoretyczny, będę prowadził w sposób metodyczny - głównie z punktu widzenia aksjologicznego, czyli szeroko rozumianej w sensie filozoficznym teorii wartości. W tym właśnie filozoficznym aspekcie niepełnosprawność można dodatkowo ujmować przez pryzmat kilku innych jeszcze działów filozofii, w tym przede wszystkim: metafizyki, antropologii i rozmaitych teorii moralności. I nawet gdybyśmy skumulowali ich ogólną wiedzę na jej temat, to jednak nie uda się nam ująć istoty niepełnosprawności w inny sposób niż tylko teoretyczny. Czy zatem żeby móc wypowiadać się na temat niepełnosprawności, należy z niepełnosprawnością zetknąć się w życiu praktycznym, może jeszcze lepiej jej doświadczyć, a nawet przeżyć? I nie chodzi tu tylko o fakt bycia niepełnosprawnym w jakimś stopniu czy odpowiadającym konkretnemu modelowi niepełnosprawności, ale przede wszystkim o obcowanie z niepełnosprawnymi jako osobami, którzy muszą borykać się z barierami w codziennym życiu, co nie stanowi zupełnie problemu dla innych ludzi. W powyższym kontekście 
niepełnosprawność i stosunek do osób niepełnosprawnych jest nie tylko czymś po prostu ludzkim, ale nawet arcyludzkim. Wydaje się, że z perspektywy kogoś, kto dopiero pierwszy raz styka się z osobami niepełnosprawnymi i ich problemami, o wiele łatwiej jest poznać terminologię oraz opanować odpowiedni język w kontakcie z nimi, niż zmienić podejście do „niepełnosprawności jako tragedii osobistej ludzi” ${ }^{1}$. Z pewnością kwestie językowe dotyczące niepełnosprawności są ważne i delikatne, szczególnie z punktu widzenia obowiązującego prawa i kultury politycznej. By je uporządkować, Konwencja o prawach osób niepełnosprawnych (dalej: Konwencja) przyjmuje „pełnoczłowieczy” model niepełnosprawności². Warto zaznaczyć, że autorzy Konwencji świadomi są ewolucji samego pojęcia niepełnosprawności, która ich zdaniem „wynika $\mathrm{z}$ interakcji między osobami z dysfunkcjami a barierami wynikającymi z postaw ludzkich i środowiskowymi, które utrudniają tym osobom pełny i skuteczny udział w życiu społeczeństwa, na zasadzie równości z innymi osobami”’3. Poza tym powszechność praw osób niepełnosprawnych i związane $\mathrm{z}$ ich przestrzeganiem problemy świadczą dodatkowo o uniwersalnym charakterze niepełnosprawności, czego współczesnym rezultatem jest ich „umiędzynarodowienie i upolitycznienie”4. To m.in. dlatego „Państwa Strony Konwencji wyrażają przekonanie, że jako powszechna i całościowa, Konwencja międzynarodowa ma na celu popieranie oraz ochronę praw i godności osób niepełnoprawnych oraz istotnie przyczyni się do zaradzenia głęboko niekorzystnej sytuacji społecznej osób niepełnosprawnych i będzie promować ich udział w sferze obywatelskiej, politycznej, gospodarczej, społecznej i kulturalnej, na zasadach równych szans"5. Małgorzata Szeroczyńska, analizując różne, a przy tym mniej lub bardziej precyzyjne definicje niepełnosprawności, które pojawiają się w ustawodawstwie polskim, również wychodzi od ogólnego stwierdzenia, że „za osobę niepełnosprawną należy uznać osobę, której niepełnosprawność wywiera skutki w każdej dziedzinie życia"6.

Dokonując jednak filozoficznej refleksji na temat pojęcia niepełnosprawności, w sensie metafizycznym można spróbować określić ją na sposób Arystotelowski - jako nadmiar albo częściej niedobór czy nawet brak czegoś, co jest potrzebne i zazwyczaj dostępne w życiu, aczkolwiek niekoniecznie niezbędne do życia. Ujmowaną $\mathrm{w}$ ten sposób niepełnosprawność trudno umieścić gdzieś między skrajno-

1 C. Barnes, G. Mercer, Niepełnosprawność, przekł. P. Morawski, Warszawa 2008, s. 26-27.

2 Zob. K. Kurowski, Niepełnosprawność i osoba niepełnosprawna-od medycznego do społecznego modelu niepełnosprawności, [w:] Najważniejsze wyzwania po ratyfikacji Konwencji o Prawach Osób Niepełnosprawnych, red. A. Błaszczak, Warszawa 2012, s. 8-15. (Dz.U. z 2012 r. poz. 1169), Preambuła, pkt (e), s. 2; zob. M. Paluszkiewicz, Prawne pojęcie niepełnosprawności, „Studia Prawno-Ekonomiczne” 2015, t. 95, s. 77-98.

4 Por. C. Barnes, G. Mercer, Niepełnosprawność, s. 152.

5 Por. punkt (y) Preambuły z art. 1 w: Cel Konwencji o prawach osób niepełnosprawnych ONZ, s. 3-4.

6 M. Szeroczyńska, Niepełnosprawność i osoba niepełnosprawna. Definicje, [w:] Polska droga do Konwencji o prawach osób niepełnosprawnych ONZ, red. A.M. Waszkielewicz, Kraków 2008, s. 12. 
ściami nadmiaru lub braku czegoś, co odpowiadałoby modelowi tzw. złotego środka jako klucza do poszukiwania indywidualnego szczęścia. W takim kontekście każda osoba niepełnosprawna określa swój własny „złoty środek” w zależności od tego, z jakim brakiem lub niedoborem się zmaga. Medycznie rzecz biorąc, niepełnosprawność wiąże się najczęściej z chorobami, procesami starzenia się, nadmiernego zużycia i wypadkami. Mechanicznie natomiast może wiązać się z wadami, uszkodzeniami, niewłaściwym działaniem bądź korzystaniem, co potocznie nazywamy zepsuciem, w rezultacie którego niepełnosprawność się pojawia. Odpowiada to w pewien sposób zapisowi z Konwencji, która „do osób niepełnosprawnych zalicza te osoby, które mają długotrwale naruszoną sprawność fizyczną, umysłową, intelektualną lub w zakresie zmysłów, co może $\mathrm{w}$ oddziaływaniu $\mathrm{z}$ różnymi barierami, utrudnić im pełny i skuteczny udział w życiu społecznym, na zasadzie równości z innymi osobami"

W drugim wskazanym ujęciu - antropologicznym - nad niepełnosprawnością możemy się zastanawiać w wymiarze filozoficznym, ujmując człowieka w sensie psycho-fizycznym jako zindywidualizowaną osobę, ale będącą częścią jakiejś wspólnoty o charakterze społecznym, np. rodziny, państwa itp. Bez wątpienia niepełnosprawność pozwala poznać lepiej każdego człowieku mającego z nią jakikolwiek kontakt pośredni bądź bezpośredni, uczy bowiem właściwych relacji międzyludzkich, zwłaszcza empatii i poświęcenia, co nadaje tym wzajemnym relacjom także charakter moralny.

A zatem $\mathrm{w}$ trzecim ujęciu niepełnosprawność należy wiązać z etyką i rozmaitymi teoriami moralności, które szukają wytłumaczenia, a może raczej jakiegoś jej usprawiedliwienia. Przy takim podejściu niepełnosprawności próbuje się nadać sens, wyznaczając najczęściej konkretny cel. Jedną z najprostszych dróg, które mogą być przydatne do jego osiągnięcia, jest skierowanie się ku wartościom, zwłaszcza tym wyższym, zwanym ideami, dzięki którym w każdym życiu można odnaleźć swój własny i niepowtarzalny sens. Dlatego z punktu widzenia rozwoju moralnego człowieka tak ważna staje się celowość ukierunkowana na owe wartości. Okazuje się przy tym, że ludzie niepełnosprawni dużo lepiej wiedzą, czym jest prawdziwe dobro i szczęście, jak cieszyć życiem, a nade wszystko, jak radzić sobie $\mathrm{z}$ jego problemami i trudami, które mogą wydawać się prozaiczne dla kogoś, kto nie doświadczył nigdy dysfunkcjonalności. W zasadzie osoby niepełnosprawne tego nie mówią, gdyż nie muszą - one po prostu pokazują, jak należy żyć i w tym życiu zwyciężać. Poza tym ludzie niepełnosprawni starają się być doskonali w tym, co robią, w miarę możliwości, jakie mają. Wykorzystują je do granic - właściwie wszystko, co robią, robią na maksimum. Ich postawa jest maksymalistyczna, gdyż wynika z konieczności, a nie tylko możliwości. Dodatkowo posta- 
wa ich jest tak silnie umotywowana, że wydobywa niebywałe pokłady sił witalnych i siły woli, do których zdolny jest człowiek jedynie w przypadkach ekstremalnych sytuacji życiowych.

\section{Racjonalne podejście do problemów wynikających $\mathrm{z}$ niepełnosprawności}

To oczywiste, że „człowiek jest podobny do człowieka, a jeśli chodzi o istotę człowieczeństwa - wszyscy jesteśmy tacy sami”. Niepełnosprawność słusznie wiążemy przede wszystkim $\mathrm{z}$ istotą naszego człowieczeństwa, ale w sensie uniwersalnym - niepełnosprawność dotyczy podobnie jak nas - ludzi - wszystkich istot żywych, w tym przede wszystkim zwierząt. Należymy bowiem do tego samego świata przyrody, podlegając jego prawom. W tym kontekście niepełnosprawność dotyczy samej natury, wiąże się bowiem z życiem, zwłaszcza tym organicznym, pojmowanym „jako proces czysto mechaniczny" . Podążając tym tokiem rozumowania, niepełnosprawność ściśle związaną z życiem możemy ujmować przez pryzmat trzech kartezjańskich nauk wyrastających z fizykalnego pnia drzewa wiedzy, czyli medycyny, mechaniki i etyki. Racjonalistyczne podejście do metafizyki, w tym ontologii człowieka, zakłada dualizm substancji: res extensa i res cogitans. Dlatego człowiek to istota składająca się z rozciągłego ciała (materii) i myślącego ducha (formy) ${ }^{10}$. Jest ujmowany jako maszyna psychofizyczna, z założenia w sposób najlepszy z możliwych łącząca w sobie to, co zmysłowe, z tym, co rozumne. Jej główny problem polega jednak na tym, że choć doskonała z założenia w swym istnieniu (teoretycznie), nie zawsze jest doskonała w swoim, zwłaszcza jednostkowym, życiu (praktycznie).

W tym momencie warto podkreślić, że z punktu istnienia samej natury wartością numer jeden łączącą wszystkie powyższe nauki jest wartość samego życia. Podobnie rzecz się ma z niepełnosprawnością, która jest czymś naturalnym, a zatem jest związana z życiem. Racjonalizm, przypisujący naturze rozumność, każde życie poddaje tym samym logicznym prawom, mogąc nie tylko określać jego cele, ale także nadawać mu sens. W związku z tym uniwersalny jej wymiar polega na tym, że niepełnosprawność o wiele bardziej łączy, niż dzieli wszystkich ludzi. Poza tym każdy może stać się niepełnosprawnym $\mathrm{z}$ różnych przyczyn właściwie w każdym momencie swojego życia - zarówno na czas określony, jak i nieokreślony.

Niepełnosprawność w podobny sposób dotyka ludzi różniących się rasami, narodowością, językami, poglądami, wiekiem, płcią itp. Trzeba zdawać sobie sprawę

\footnotetext{
$8 \quad$ M. Komorowska, Stereotypy dotyczące dzieci i młodzieży niesłyszącej, [w:] Stereotypy a kształtowanie świadomości człowieka, red. A. Kryniecka, Białystok 2017, s. 377.

9 W. Tatarkiewicz, Historia filozofii, t. 2: Filozofia nowożytna do roku 1830, Warszawa 1990, s. 50.

10 Por. S. Rzepczyński, Kartezjusz, [w:] Słownik myśli filozoficznej, oprac. M. Kuziak et al., Bielsko-Biała 2006 s. $149-150$.
} 
z tego, że nawet jeśli nie jesteś niepełnosprawnym dziś, możesz stać się nim w przyszłości. Dla większości z nas wydaje się to niewyobrażalne lub przerażające, ale biorąc pod uwagę rozwój nauki i technologii, w tym wspomnianej medycyny i mechaniki, możemy jednak w przyszłość spoglądać z pewnym optymizmem, twierdząc, że mankamenty związane $\mathrm{z}$ każdym rodzajem niepełnosprawności uda się przynajmniej zniwelować. Dlatego nadal najtrudniejsze zadanie w kontekście rozważań dotyczących niepełnosprawności wiąże się z etyką. To właśnie ze stworzeniem teorii moralności opartej na swojej niezawodnej metodzie również sam Kartezjusz miał największy problem. W związku z tym sformułował jedynie jej zasady tymczasowe, które jak najbardziej należy wykorzystywać w praktyce. Zdaniem Marii Szyszkowskiej „troska o ciało staje się w filozofii Kartezjusza nakazem etycznym. Bowiem to, co w ciele jest działaniem mechanicznym - w duszy staje się namiętnością. Płynie stąd wniosek o doniosłości medycyny. Właściwe kierowanie mechanizmami ciała sprzyja pożądanym zmianom w sferze namiętności”"11.

Formułując zasady etyki tymczasowej, Kartezjusz stwierdza, że „(...) aby nie pozostać zupełnie niezdecydowanym co do swych czynów w czasie (...) oraz, aby nie zaprzestać od owej chwili żyć najszczęśliwiej, jak tylko można, urobiłem sobie moralność tymczasową, składającą się zaledwie z trzech czy czterech zasad postępowania, którymi chętnie się z wami podzielę"12, a które jak najbardziej można odnieść do życia związanego z jakąkolwiek niepełnosprawnością.

W myśl pierwszej ze swoich zasad etyki tymczasowej Kartezjusz proponuje być „posłusznym prawom i obyczajom swego kraju, trzymając się wytrwale religii, w której dzięki łasce Bożej byłem od dzieciństwa chowany, i kierując się we wszystkich innych sprawach mniemaniami najbardziej umiarkowanymi i najdalszymi od krańcowości, które są powszechnie przyjęte w postępowaniu najrozsądniejszych wśród tych, z którymi miałbym współżyć. Przestając bowiem od tej chwili liczyć się z moimi własnymi mniemaniami (...), byłem pewien, że nie pozostało mi nic lepszego, jak trzymać się poglądów ludzi najrozsądniejszych"13. Stosując się do założeń tej zasady, w momencie zetknięcia się z niepełnosprawnością (bezpośrednio czy pośrednio) należy jak najszybciej oswoić się z nią, godząc ze swoim losem, być może przeznaczeniem dla wierzących z Bogiem. Jest to pierwszy i zarazem najtrudniejszy w sensie etycznym krok, który wymaga pokory i cierpliwości. Postawa przeciwna, oparta na namiętnościach i buncie, zawsze będzie bardziej szkodzić, a na pewno w sytuacji niepełnosprawności nie będzie pomagać. Praktycznym celem takiej postawy staje się realna i logiczna propozycja przyjęcia, a jeszcze lepiej pokochania być może na nowo życia takiego, jakie jest. Do osiągnięcia tego celu szczegól-

11 M. Szyszkowska, Filozofia w Europie, Białystok 1999, s. 125.

12 R. Descartes, Rozprawa o metodzie właściwego kierowania rozumem i poszukiwania prawdy w naukach, przekł. W. Wojciechowska, Warszawa 1981, s. 27. 
nie przydatne okazują się: współdziałanie, zaufanie, umiar, a nawet wiara. Ta ostatnia jest szczególnie przydatna do pojęcia cierpienia, zwłaszcza poprzez nadanie mu wartości i sensu. Właśnie o sile wiary w Stwórcę, która rozprasza ciemności niczym „morska latarnia”, i o cierpieniu jako lekcji w światowym bestsellerze, opatrzonym sloganem „Bez rąk, bez nóg, bez ograniczeń”, pisze australijski kaznodzieja Nick Vujicic, doradzając innym, podobnie jak on niepełnosprawnym ${ }^{14}$. Aby nie dopuszczali „do tego, by jej światło przygasło w wyniku (...) zaniedbania. Pod wpływem kryzysu zrozumiałem, że muszę pozwolić swojej wierze świecić15 (...). Poczułem się naprawdę szczęśliwy dopiero kiedy zastosowałem wiarę w działaniu i powierzyłem swoje życiu Bogu. On pokazał mi, że jestem doskonale - niedoskonały, właśnie takim, jakim mnie zaprojektował"16.

W powyższym kontekście cierpienie jak najbardziej ma charakter uniwersalny, prowadzi bowiem do zrozumienia i poznawania innych ludzi ${ }^{17}$. Jak zauważył Jan Szczepański, ludzie bronią się przed nim, mimo iż „jest (...) tym wspólnym światem przeżyć, gdzie spotykają się wszyscy wielcy i mali, biedni i bogaci, wierzący i niewierzący, panujący i poddani, wszyscy jednakowo prawie wyposażeni w zdolność odczuwania cierpienia i w mechanizmy jego unikania. Lecz różnimy się bardzo $\mathrm{w}$ sposobach radzenia sobie $\mathrm{z}$ cierpieniem"18. Powyższe podejście odpowiada założeniom teodycei sformułowanej przez Leibniza ${ }^{19}$, którą w znakomity sposób objaśnił Leszek Kołakowski, pisząc: „samo istnienie rzeczy, skoro jest zawsze współistnieniem, rodzi cierpienie, lepszy jednak świat, w którym się cierpi, niż nicość wolna od cierpień. Teodycea nie tylko więc usprawiedliwia życie skromnymi wymiarami zła, ale zło samo usprawiedliwia jako konieczny składnik doskonałego kosmosu" ${ }^{20}$. O wiele łatwiej mówi się o cierpieniu, zwłaszcza innych, trudniej je znosić, gdy dotyka nas albo naszych bliskich. To właśnie jest najtrudniejsze do pojęcia i raczej nie będzie tego w stanie dokonać samodzielnie rozum, bez konieczności dodatkowego rozwijania, także sfery woli i uczuć.

Drugą zasadą sformułowaną przez Kartezjusza „było, żeby być w czynach swych w miarę możności jak najbardziej stanowczym i stałym i trzymać się mniemań nawet najbardziej wątpliwych z chwilą, gdym się raz wreszcie na nie zdecydował, nie mniej wytrwale, niż gdyby były bardzo pewne"21. W tym przypadku należy brać pod uwagę perfekcyjnie zaplanowaną organizację dnia, a nawet każdej godziny

16 Ibidem, s. 148.

17 J. Szczepański, Sprawy ludzkie, Warszawa 1988, s. 12.

18 Ibidem, s. 13.

19 Zob. G.W. Leibniz, Teodycea: o dobroci Boga, wolności człowieka i pochodzeniu zła, przekł. M. Frankiewicz, Warszawa 2001.

20 L. Kołakowski, Kultura i fetysze, Warszawa 2010, s. 144.

21 R. Descartes, Rozprawa o metodzie..., s. 29.
} 
życia. Metoda kartezjańska zakłada, że doskonały plan jest w stanie pomóc rozwiązać każdy problem. Powyższa zasada zachęca do zorganizowania się, konsekwencji, zaparcia i wytrwałości, co ma znacznie ułatwić życie - dając siłę zarówno fizyczną, jak i psychiczną. Praktycznym jej celem będzie niesienie zawsze nadziei na poprawę życia, zwłaszcza w chwilach beznadziejności i zwątpienia. Dlatego też należy trzymać się swojego planu, być zdecydowanym i pewnym siebie. Przecież życie nieustannie wymaga, by iść ciągle naprzód, czyli „kroczyć w miarę możności jak najprościej w tym samym kierunku i nie zmieniać go dla błahych powodów”, tym bardziej nigdy nie cofać się i nie zatrzymywać, dzięki czemu będzie można poczuć się lepiej niż jak ktoś zagubiony w środku lasu ${ }^{22}$. Wspomniany Nick Vujicic zachęca niepełnosprawnych do tego, by odkrywali swoją pasję, określili cel, a następnie zorganizowali swoje życie tak, by mogli rozwijać otrzymane zdolności i w pełni wykorzystywać ich potencjał ${ }^{23}$.

Trzecia zasada postępowania według Kartezjusza to „usiłowanie, aby zawsze przezwyciężać raczej siebie aniżeli los, oraz zmieniać raczej swe życzenia aniżeli porządek świata; i w ogóle wyrobić sobie przeświadczenie, że poza myślą nie ma nic, co by było w sposób bezwzględny w naszej mocy" ${ }^{24}$. Filozof, dokonując tu pewnego podsumowania swoich dotychczasowych zasad, proponuje każdemu kierującemu się rozumem, aby rozbudowywać i odpowiednio wzmacniać swoją zindywidualizowaną sferę motywacyjną poprzez uświadomienie sobie konieczności walki o siebie, głównie ze swoimi słabościami i namiętnościami. Ta zasada uczy i wymaga odwagi w życiu, w którym nie można poddawać się, zachowując wiarę w siebie, innych ludzi i optymistycznie nie tylko spoglądając, ale także wchodząc w przyszłość. Doskonale zdawała sobie $\mathrm{z}$ tego sprawę chociażby Jane Hawking, żona sparaliżowanego brytyjskiego uczonego Stephena, która w swoich wspomnieniach, zmagając sie na co dzień z kalectwem męża, pisała: „jeśli nie będę ustawała w wierze i nadal będę starała się z całych sił, kiedyś nadejdzie jaśniejszy, spokojniejszy dzień”25.

Kartezjańskie zasady etyki tymczasowej można potraktować jako pewnego rodzaju receptę na życie, sprowadzając je do trzech podstawowych wartości: wiary, nadziei i miłości. Choć w teologii są to cnoty boskie, prowadzące do świętości jako największego szczęścia, to w sferze moralności - zwłaszcza praktycznego obcowania $\mathrm{z}$ innymi, w tym niepełnosprawnymi - są to cechy najlepsze ze wszystkich możliwych i najbardziej ludzkie ${ }^{26}$. Należy przy tym podkreślić, że wszystkie

\footnotetext{
22 Por. ibidem, s. 29.

23 Por. N. Vujicic, Niezwyciężony! Potęga..., s. 99.

24 R. Descartes, Rozprawa o metodzie..., s. 30.

25 J. Hawking, Podróż ku nieskończoności: moje życie ze Stephenem, przekł. J. Żuławnik, Warszawa 2013 , s. 463-464.

26 Zob. A. Maliszewska, Kościół wobec niepełnosprawności: dobroczynność a miłosierdzie. Stanowisko wybranych teologów niepełnosprawności, „Prace Naukowe Uniwersytetu Śląskiego w Katowicach” 2018, nr 3743 s. $178-192$
} 
powyższe cnoty mają charakter irracjonalny, a ich wartość paradoksalnie podkreśla sam rozum.

\section{Jak żyć z niepełnosprawnością - udowadniają sami niepełnosprawni}

Tak czy inaczej, w sensie etycznym niezwykle trudno jest odpowiedzieć na pytanie, dlaczego dotknęła kogoś niepełnosprawność. Może w tej kwestii rację miał Seneka, który dokonując refleksji w dialogu O Opatrzności, pytał: dlaczego nieszczęścia dotykają zacnych ludzi? i odpowiedział: „bo przecież i na wojnie niebezpieczne rozkazy otrzymują najdzielniejsi" ${ }^{27}$. Podobnie rzecz ujmując, stoik ten stwierdził, że tak jak ogień jest próbą złota, tak nieszczęście jest próbą dzielnych ludzi ${ }^{28}$. Warto się zastanawiać nad tym, czy aby na pewno niepełnosprawność należy utożsamiać z nieszczęściem. Obserwując ludzi niepełnosprawnych, dojdzie się szybciej do zupełnie innego wniosku. Nawet jeśli człowiek niepełnosprawny będzie czuł się nieszczęśliwy, to ma do tego o wiele bardziej zasadny powód niż większość ludzi. Niepełnosprawni we wszystkim, co czują i co robią, są autentyczni. O wiele częściej okazują swoje uczucia, wyrażają swoje pragnienia, cieszą się tym, czym mogą, a nie tym, czego chcą, przez co są najbardziej ludzcy. Niepełnosprawność zazwyczaj napawa ludzi lękiem ${ }^{29}$, który jednak powinniśmy przezwyciężać. W ten sposób zetknięcie się z jakimkolwiek rodzajem niepełnosprawności, zarówno własnej czy też innych ludzi, wymaga przede wszystkim odwagi.

Niepełnosprawni oraz osoby zmagające się z wynikającymi z niej trudnościami są zatem prawdziwymi bohaterami na co dzień. Szczególnie inspirujące, a zarazem docierające praktycznie do wszystkich, nawet mało tym zainteresowanych, są przykłady wzięte z życia konkretnych osób niepełnosprawnych, które zyskały powszechny rozgłos, a nawet sławę. Nie przyniosła im tego sama niepełnosprawność, lecz to, w jaki sposób ze swoją niepełnosprawnością żyją, potocznie mówiąc, pełnią życia czy też życia „na maksa” swoich możliwości. W zasadzie niepełnosprawni swoim przykładem uświadamiają nam, co powinno być najważniejsze w życiu. Osoby niepełnosprawne nie tylko potrafią w znakomity sposób pokazać, jak skutecznie radzić sobie $\mathrm{z}$ barierami w świecie związanym $\mathrm{z}$ ich niepełnosprawnością, ale po prostu pokazują, jak należy się realizować. Sparaliżowany od dziecka w wyniku porażenia mózgowego irlandzki malarz, pisarz i poeta Christy Brown, który mógł poruszać i zarazem tworzyć (malować/pisać) jedynie lewą stopą ${ }^{30}$, powie-

„Quia in castris quoque periculosa fortissimis imperantur”, De Providentia 4, 6-8, [w:] L.A. Seneka, Myśli, przekł. S. Stabryła, Kraków 1989, s. 43.

„Ignis aurum probat, miseria fortes viros”, De Providentia 5, 10, [w:] ibidem, s. 51.

Por. M. Komorowska, Stereotypy dotyczące dzieci..., s. 374 i 375.

Zob. autobiografię Christy Browna (1932-1981): My Left Foot, New York 1990. Powieść doczekała się adaptacji filmowej w 1989 r.: My Left Foot: The Story of Christy Brown, której reżyserem jest Jim Sheridan, a w rolę bohatera wcielił się Daniel Day-Lewis. 
dział: „Bez przerwy pisałem i pisałem, nieświadom, gdzie się znajduję, godzina za godziną. Doznawałem wrażenia, że jestem inną osobą. Nie byłem już nieszczęśliwy. Nie czułem się pokrzywdzony ani zamknięty w odosobnieniu. Byłem wolny, mogłem myśleć, żyć, tworzyć... Czułem ulgę i ukojenie, mogłem być sobą... I chociaż nie było mi dane poznać radości tańca, doznałem rozkoszy tworzenia” ${ }^{31}$.

$\mathrm{W}$ podobnym tonie o swojej niepełnosprawności mawiał legendarny już Stephen Hawking, który w jednym z wywiadów powiedział, że „irytowanie się na moją niesprawność byłoby stratą czasu. Ludzie nie mają czasu dla kogoś, kto się zawsze złości lub narzeka. Trzeba iść ze swym życiem do przodu, i myślę, że udawało mi się to nieźle" 32 . O zmarłym w 2018 r., a zmagającym się od 21. roku życia ze stwardnieniem zanikowym bocznym (ALS) brytyjskim uczonym możemy dzisiaj powiedzieć, że radzenie sobie nieźle to stanowczo zbyt mało. Zwłaszcza wtedy, gdy przywołamy jeszcze jedno wspomnienie jego pierwszej żony Jane, według której „Stephen sprawiał wrażenie przerażająco słabego i bezradnego. Doprawdy trudno sobie wyobrazić większe fizyczne kalectwo" ${ }^{33}$.

Wymownie swoje życie z niepełnosprawnością podsumował także Maciej Białek, niewidomy nauczyciel historii z VIII LO im. Zofii Nałkowskiej w Lublinie, który w wywiadzie dla „Kuriera Lubelskiego” stwierdził: „Dla mnie szczęściem jest to, że żyję i ciągle doznaję nowych przeżyć" ${ }^{34}$. Paradoksalnie niepełnosprawność często sprawia, że ludzie nią dotknięci by żyć, muszą wznosić się na wyżyny swoich ograniczonych możliwości. Przekraczając owe ograniczenia, udowadniają, że mogą działać właściwie we wszystkich sferach życia: w sporcie, biznesie, nauce, sztuce, polityce itp. Obecnie coraz częściej mogą realizować swoje plany, a jednocześnie rozwijać pasje i samych siebie.

Choć powyższe przykłady, jak i wiele innych przykładów osób niepełnosprawnych, szczególnie ukazanych jako bohaterów filmowych, są dość stereotypowe, na pewno uproszczone i zbyt wyidealizowane, a przez to nie do końca prawdziwe ${ }^{35}$, to jednak lepiej jest eksponować tych, którzy potrafili z ofiary stać się herosami, i to nie tylko filmowymi ${ }^{36}$. Oczywiście nie każdemu może się to udać na miarę tych,

31 H. Adler, Umiejętność realizowania marzeń, przekł. B. Moryń, Łódź 1997, s. 4.

32 Zob. wywiad ze Stephenem Hawkingiem (1942-2018): A. Jha, As quoted in "Return of the time lord”, „The Guardian”, 27.08.2005, https://www.theguardian.com/science/2005/sep/27/scienceandnature.highereducationprofile [dostęp: 27.09.2005], cyt. za: https://www.wielkieslowa.pl/475-irytowanie-sie-na-moja-niesprawnosc-byloby-strata-czasu.html [dostęp: 4.06.2019].

33 J. Hawking, Podróż..., s. 443.

34 Zob. M. Szlachetka, Maciej Białek: Nie rozpamiętuję codziennie tego, że jestem niewidomy. Oswoiłem się, Kurier Lubelski, 18.01.2015, https://kurierlubelski.pl/maciej-bialek-nie-rozpamietuje-codziennie-tego-ze-jestem-niewidomy-oswoilem-sie/ar/3718216 [5.06.2019]. Historia Macieja Białka stała się inspiracją do filmu Jacka Lusińskiego: Carte Blanche z 2015 r., z rolą główną Andrzeja Chyry.

35 Por. C. Barnes, G. Mercer, Niepełnosprawność, s. 115-116.

36 Por. P. Stanisławski, Od ofiary do herosa, http://www.niepelnosprawni.pl/ledge/x/7828?fbclid=lwAR2vcSIh4nKMjJcMvITSZI5v8TfpsQ_iDJAYqFLIOpKOQpAGibtA7-728E [dostęp: 20.07.2020]. 
których zauważyły media i którzy odnieśli światowy sukces. Problem ten nie dotyczy w tym przypadku tylko osób niepełnosprawnych, ale w ogóle ludzi, którzy chcą być postrzegani jako bohaterowie, wykorzystując swoje tzw. pięć minut. Niepełnosprawni są jednak tymi ludźmi, którzy niczego nie muszą udowadniać, gdyż bohaterstwo potwierdzają w codziennym życiu.

\section{Czy na pewno utopijne zakończenie?}

W swojej pracy naukowej, badając od wielu lat utopie jako światy, które realnie nie istnieją (gr. ou-topos = nieistniejące miejsce) bądź które są przedstawiane jako najlepsze z możliwych (gr. eu-topos = dobre miejsce), nie sposób było nie dojść do oczywistego przecież wniosku, iż są to światy wymyślone. Pierwotnie jako gatunek literacki co do formy (najczęściej powieści) można je także rozpatrywać w sensie bogactwa zawartych w nich różnorodnych treści: filozoficznych, społecznych, ekonomicznych, politycznych i prawnych. Utopie nie są przy tym krainami, w których ich mieszkańcy nie mają żadnych problemów. Przeciwnie - utopie są uznawane za krainy doskonałe właśnie dlatego, że ich mieszkańcy potrafią radzić sobie z problemami, z którymi borykamy się również my, ale nie potrafimy ich tak skutecznie jak oni rozwiązywać ${ }^{37}$.

Dlatego w kontekście niepełnosprawności jako rzeczywistego problemu utopie - zwłaszcza jeśli zaliczymy do nich rozwój tego gatunku podążający w kierunku science-fiction ${ }^{38}$, ze szczególnym uwzględnieniem wzmożonego postępu technologicznego i osiągnięć naukowych - mogą być światłem ${ }^{39}$ dającym optymizm, zwłaszcza na poprawę życia w nadchodzącej przyszłości. Optymizm ten ściśle wiążę się z utopijnym przekonaniem, iż można wieść życie dobre i szczęśliwe, a przynajmniej takim starać się je czynić w świecie, w którym żyjemy ${ }^{40}$. Jednakże w kontekście współczesnej globalizacji i związanego z nią rozwoju gospodarczego, technologicznego, kulturowego i prawnego wciąż najbardziej niepokojące pozostają dyskryminacja osób niepełnosprawnych ${ }^{41}$ oraz ich wykluczenie z życia społecznego ${ }^{42}$. Wydaje się, że w pewnym zakresie podejście proponowane w utopiach społecznych może pomóc temu zaradzić. Utopie bowiem zakładają, po pierwsze, że to,

37 Por. K. Kuźmicz, Francuskie utopie oświeceniowe jako wyraz kultury politycznej i prawnej swoich czasów, „Miscellanea Historico-luridica” 2016, t. 15, z. 2, s. 260.

40 Por. K. Kuźmicz, Utopia i antyutopie a totalitaryzm. Refleksje filozoficznoprawne, [w:] O prawie i jego dziejach księgi dwie. Studia ofiarowane Profesorowi Adamowi Lityńskiemu w czterdziest

41 Zob. T. Degener, Disability in Human Rights Context, „Laws” 2016, nr 5(35), https://doi.org/10.3390/ laws5030035.

Por. C. Barnes, G. Mercer, Niepełnosprawność, s. 167-168. 
co było dotychczas niemożliwe, $\mathrm{z}$ upływem czasu staje się często rzeczywiste, a zatem świat i życie można uczynić lepszym, a zwłaszcza poprawić błędy, niedogodności i wszelkie mankamenty, do czego utopijne myślenie zachęca. Po drugie, utopie, zakładają rozwój nauki i techniki dostępny dla każdego bez żadnych wyjątków i dla dobra całej ludzkości, w przeciwieństwie do antyutopii i dystopii. Te ostatnie nawet jeśli o takim postępie mówią, to zawsze będzie on wykorzystywany przez nielicznych kosztem większości, która jeśli zostanie do niego dopuszczana, to tylko po uwzględnieniu czynnika ekonomicznego wzrostu (np. gwarancji zysków dla tych nielicznych). Po trzecie, utopie pozytywne można traktować jako przesłania dające nadzieję na życie lepsze - zwłaszcza wtedy, gdy optymistycznie mówią o bezinteresowności działań człowieka na rzecz innych, przede wszystkim potrzebujących, w tym chociażby osób niepełnosprawnych, by pomóc im przezwyciężać wszelkie napotykane bariery i poprawiać, o ile tylko się to da, warunki ich dotychczasowego życia. W tym celu utopie mogą być przydatne głównie poprzez wykorzystanie drzemiącego w nich i ujawnianego potencjału technologicznego oraz licznych sposobów na zorganizowanie doskonałego życia wspólnotowego. To drugie, aby uznać za doskonałe, powinno przynajmniej umiejętnie rozwiązywać wszystkie swoje problemy, optymistycznie łącząc się z kultem i szacunkiem dla każdego bez wyjątku życia - zwłaszcza jednak życia tych wszystkich, którzy zmagają się z problemami generującymi jakikolwiek trud i cierpienie.

\section{Akty prawne}

Konwencja o prawach osób niepełnosprawnych, sporządzona w Nowym Jorku dnia 13 grudnia 2006 r. (Dz.U. z 2012 r. poz. 1169).

\section{Literatura}

Adler H., Umiejętność realizowania marzeń, przekł. B. Moryń, Łódź 1997.

Baczko B., Światła utopii, przekł. W. Dłuski, Warszawa 2016.

Barnes C., Mercer G., Niepetnosprawność, przekł. P. Morawski, Warszawa 2008.

Brown Ch., My Left Foot, New York 1990.

Degener T., Disability in Human Rights Context, „Laws” 2016, nr 5(35), https://doi. org/10.3390/laws5030035.

Descartes R., Rozprawa o metodzie właściwego kierowania rozumem i poszukiwania prawdy w naukach, przekł. W. Wojciechowska, Warszawa 1981.

Hawking J., Podróż ku nieskończoności: moje życie ze Stephenem, przekł. J. Żuławnik, Warszawa 2013.

Jha A., As quoted in „Return of the time lord”, „The Guardian”, 27.08.2005, https://www.theguardian.com/science/2005/sep/27/scienceandnature.highereducationprofile.

Kołakowski L., Kultura i fetysze, [w:] Wielcy filozofowie, Warszawa 2010. 
Komorowska M., Stereotypy dotyczace dzieci i młodzieży niestyszacej, [w:] Stereotypy a kształtowanie świadomości człowieka, red. A. Kryniecka, Białystok 2017.

Kurowski K., Niepetnosprawność i osoba niepełnosprawna - od medycznego do społecznego modelu niepełnosprawności, [w:] Najważniejsze wyzwania po ratyfikacji Konwencji o Prawach Osób Niepetnosprawnych, red. A. Błaszczak, Warszawa 2012, „Biuletyn RPO”, Źródła 2012/10.

Kuźmicz K., Utopia i antyutopie a totalitaryzm. Refleksje filozoficznoprawne, [w:] O prawie i jego dziejach księgi dwie. Studia ofiarowane Profesorowi Adamowi Lityńskiemu w czterdziestopięciolecie pracy naukowej i siedemdziesięciolecie urodzin, Księga II, Białystok-Katowice 2010.

Kuźmicz K., Francuskie utopie oświeceniowe jako wyraz kultury politycznej i prawnej swoich czasów, „Miscellanea Historico-Iuridica” 2016, t. 15, z. 2.

Leibniz G.W., Teodycea: o dobroci Boga, wolności człowieka i pochodzeniu zła, przekł. M. Frankiewicz, Warszawa 2001.

Leś M.M., Fantastyka socjologiczna. Poetyka i myślenie utopijne, Białystok 2008.

Maliszewska A., Kościót wobec niepełnosprawności: dobroczynność a miłosierdzie. Stanowisko wybranych teologów niepełnosprawności, „Prace Naukowe Uniwersytetu Śląskiego w Katowicach" 2018, nr 3743.

Paluszkiewicz M., Prawne pojęcie niepetnosprawności, „Studia Prawno-Ekonomiczne” 2015, t. 95.

Rzepczyński S., Kartezjusz, [w:] Słownik myśli fi lozoficznej, oprac. M. Kuziak et al., Bielsko-Biała 2006.

Seneka L.A., Myśli, przekł. S. Stabryła, Kraków 1989.

Słownik myśli filozoficznej, oprac. M. Kuziak et al., Bielsko-Biała 2006.

Stanisławski P., Od ofiary do herosa, http://www.niepelnosprawni.pl/ledge/x/7828?fbclid= IwAR2vcSIh4nKMjJcMvITSZI5v8TfpsQ_iDJAYqFLlOpKOQpAGibtA7-728E.

Szczepański J., Sprawy ludzkie, Warszawa 1988.

Szeroczyńska M., Niepetnosprawność i osoba niepetnosprawna. Definicje, [w:] Polska droga do Konwencji o prawach osób niepetnosprawnych ONZ, red. A.M. Waszkielewicz, Kraków 2008.

Szlachetka M., Maciej Białek: Nie rozpamiętuję codziennie tego, że jestem niewidomy. Oswoiłem się, Kurier Lubelski, 18.01.2015, https://kurierlubelski.pl/maciej-bialek-nie-rozpamietuje-codziennie-tego-ze-jestem-niewidomy-oswoilemsie/ar/3718216.

Szyszkowska M., Filozofia w Europie, Białystok 1999.

Tatarkiewicz W., Historia filozofi, t. 2: Filozofia nowożytna do roku 1830, Warszawa 1990.

Vujicic N., Niezwyciężony! Potęga wiary w działaniu, przekł. P. Kwiatkowski, Wrocław 2014. 